\title{
African Art: The Journey from Ethnological Collection to the Museum of $\mathrm{Art}^{1}$
}

\author{
Aneta Pawłowska
}

Prof. Aneta Pawłowska, PhD.

Department of Art History

University of Lódź

https://orcid.org/0000-0003-2847-4403

aneta.pawlowska@uni.lodz.pl

Muzeológia a kultúrne dedičstvo, 2020, 8:4:161-176

DOI: $10.46284 / \mathrm{mkd} .2020 .8 .4 .10$

African Art: The Journey from Ethnological Collection to the Museum of Art

This article aims to show the transformation in the way African art is displayed in museums which has taken place over the last few decades. Over the last 70 years, from the second half of the twentieth century, the field of African Art studies, as well as the forms taken by art exhibitions, have changed considerably. Since W. Rubin's controversial exhibition Primitivism in 20 th Century Art at MoMA (1984), art originating from Africa has begun to be more widely presented in museums with a strictly artistic profile, in contrast to the previous exhibitions which were mostly located in ethnographical museums. This could be the result of the changes that have occurred in the perception of the role of museums in the vein of new museology and the concept of a "curatorial turn" within museology. But on the other hand, it seems that the recognition of the artistic values of old and contemporary art from the African continent allows art dealers to make large profits from selling such works. This article also considers the evolution of the idea of African art as a commodity and the modern form of presentations of African art objects. The current breakthrough exhibition at the Bode Museum in Berlin is thoroughly analysed. This exhibition, entitled Beyond compare, presents unexpected juxtapositions of old works of European art and African objects of worship. Thus, the major purpose of this article is to present various benefits of shifting meaning from "African artefacts" to "African objects of art," and therefore to relocate them from ethnographic museums to art museums and galleries.

Keywords: African art, museum, exhibitions, contemporary art, Beyond Compare

\section{Introduction}

The study of African and any other non-European art is a fascinating matter. On the one hand, it is driven by the thrust of recent multidisciplinary work on colonial discourse and decries the ethnocentrism of traditional anthropology. Such an opinion was presented by the American historian, Roy Sieber (1923-2001), who is considered to be the founder of the discipline of African art history in the United States: "Many anthropological theories imply a cultural timelessness and, focusing upon the fiction of an ethnographic present, ignore the cumulative effect of changes (...), upon the shape of a culture and its art". ${ }^{3}$

On the other hand, the study of African art seeks to promote the aesthetic quality of art, while attempting to distance itself from the modernist exploitation of "primitive" or "tribal"

\footnotetext{
${ }^{1}$ The issues discussed in the article were the subject of author's research internship at the University of West Bohemia (Pilsen) [ZápadočeskáUniverzita v Plzni] in the Czech Republic, financed by the Polish National Agency for Academic Exchange (NAWA) AGREEMENT No: PPN/BIL/2018/1/12/CZE/UMOWA/1.

${ }^{2}$ KREAMER, Christine Mullen. A Tribute to Roy Sieber. In: African Arts, vol. 36 no. 1, 2003, p. 12-23.

${ }^{3}$ SIEBER, Roy. Preface. In: GILLON, Werner. A Short History of African Art. London: Viking,1984, p. 12.
} 
art, but all the while knowing that unqualified assertions of aesthetic worth - or even attention to aesthetic above social quality - are contrary to current theories in cultural studies. ${ }^{4}$ Moreover, when considering traditional Sub-Saharan art, we should initially contemplate whether it is acceptable to look for a common aesthetic and cultural denominator for this whole geographical area.

Although it is beyond the scope of this article to present a comprehensive spectrum of the historiography and methodologies employed in the study and interpretation of the arts of Africa, it must be mentioned that the discipline certainly has been influenced by the methods employed in the field of anthropology. The most important of these approaches was to use its earlier evolutionary paradigm for documenting peoples and cultures and the "epistemological, methodological, ethical, and political implications" of anthropological field research, as George W. Stocking (1928-2013) pointed out in his famous text "History of Anthropology: Whence/ Whither". ${ }^{5}$ Thus along with art historical methods, Africanist art historians have employed participant-observation, surveys, questionnaires, oral histories and interviews - grounded in fieldwork - to uncover the forms, contexts, meanings, and intentions of "traditional" and "contemporary" artistic practices in Africa. In various regions without long-standing written methods for archiving information, these research strategies have been particularly relied upon in order to place the so-called traditional art forms within historical, cultural, stylistic and aesthetic contexts. Moreover, scholars in recent years have brought much transparency to African art studies, revealing and analysing the impact of colonial and neocolonial encounters, the museumification of African arts, ${ }^{6}$ the role of the art market, and the effects of urban life and globalization on tradition-based expression.

Summarizing briefly this paragraph, it can be acknowledged that all scientific disciplines undergo significant changes over a period of time, with major upheavals usually occurring every few decades. As a result of this constant evolution of our understanding of science, in the late 1940s, Fritzl Saxl (1890-1948), the famous Austrian art historian, observed and confirmed strongly that art history is truly necessary for our understanding of art. He searched for an answer to this question in his infamous essay, shockingly entitled "Why do we need art history?" 7 Today, such a question could be easily formulated again, but this time in connection to another scientific discipline, namely anthropology.

Therefore, just like Fritzl Saxl in the 1940s, I would like to pose a similar question today: Do we still need anthropology in order to genuinely and legitimately study African art today? Is it really essential and indispensable? And from such a question we can arrive at a dreadful conclusion, do we still need ethnographic museums in order to showcase art objects from Africa?

\footnotetext{
${ }^{4}$ For more on this, see: ETOUNGA-MANGUELLE, Daniel. Does Africa need a cultural adjustment program? In: HARRISON, Lawrence E \& Huntington, Samuel P. (eds). Culture Matters: How Values Shape Human Progress. New York: Basic Books, 2000, p. 66-77.

${ }^{5}$ STOCKING, George. History of Anthropology: Whence/Whither. In: STOCKING, George (ed.). Observers Observed: Essays on Ethnographic Fieldwork. Madison: University of Wisconsin Press, 1983, p. 9.

${ }^{6}$ Very interesting and still current reflections on the role of museums can be found in: GLUZIŃSKI, Wojciech. $U$ podstaw muzeologii. Warszawa: PWN, 1980, p. 109-113.

${ }^{7}$ SAXL, Fritzl. Po co nam historia sztuki. In: BIALOSTOCKI, Jan (ed). Pojeccia, problemy, metody wspótczesnej nauki o sztuce. Warszawa: PWN, 1976, p.14.
} 


\section{The beginning: African artas "artificial curiosities" in Kunst-und Wunderkammers}

In spite of the fact that a deeper kind of reflection on art and African cultures was a permanent feature of European interest at the end of the nineteenth century, the first encounters for Westerners with such works of art took place as early as the Renaissance period. The early stages of the collector's passion for terra incognita were initially manifested by the Portuguese Duke Henry the Navigator (Infante Dom Henrique, o Navegador) who, after the conquest of Ceuta by the Portuguese in 1415, began "to collect" African prisoners-of-war in Sagres, teaching them the Portuguese language so that they could be employed as guides in the colonizers' expeditions into the interior of the continent. In 1488, another renowned sailor, Bartolomeu Dias, succeeded in reaching the Cape of Good Hope in South Africa and initiated an important sea route to India and the Far East. In spite of these discoveries, the European exploration of Africa itself remained limited during the sixteenth and seventeenth centuries. ${ }^{8}$

Since Renaissance times, some artefacts and relics obtained by Europeans in Africa have been included among the "artificial curiosities" in the so-called Kunst- und Wunderkammer or cabinet de curiosités. ${ }^{9}$ Certain wealthy Europeans became quite enthusiastic collectors of these rare curiosities and displayed them with pride in their elaborate collection cabinets. Anything strange and remarkable deserved a place: exotic stones, pieces of coral, shells, reptiles, butterflies, mammals and plants, as well as coins, sculptures and textiles. Drawings of rare objects also often found a place inside these cabinets of curiosities. The most significant and valuable Kunst- und Wunderkammers from the Renaissance and Baroque periods include those that contain the vast collections of the Electors of Saxony, Archduke Ferdinand II of Tyrol and Emperor Rudolf II, who established what was perhaps the most spectacular Kunstkammer of all at the Prague Castle in the late sixteenth century, ${ }^{10}$ to mention just a few.

It should also be emphasized at this point that African artefacts in Europe, unlike European and Asian "works of art", were of more significance to the eighteenth-and nineteenth-century precursors of modern anthropologists than to art historians themselves. The artist, culture and true function and meaning of these objects were usually not recorded, being regarded as unimportant or insignificant. During the age of Enlightenment, many of these collections and cabinets of curiosities were donated to natural history museums, where they were categorized and classified in the name of science along with flora, fauna and skeletal remains. A typical example of such a procedure would be the original collection donated to the British Museum in 1753, which included 29 African objects. ${ }^{11}$

\footnotetext{
${ }^{8}$ NOWAK, Bronisław. Początki obecności europejskiej w Czarnej Afryce. In: TYMOWSKI, Michał (ed). Historia Afryki do poczatku XIX wieku. Wrocław-Warszawa-Kraków: Ossolineum, 1996, p. 765-792 and, TYMOWSKI, Michał. Europejcryyy i Afrykanie: Wrajemne odkrycia i pierwsz̨e kontakty. Toruń Wydawnictwo Naukowe Uniwersytetu Mikołaja Kopernika, 2017, p. 91-115.

${ }^{9}$ PAWŁOWSKA, Aneta. O potrzebie tworzenia kolekcji sztuki afrykańskiej. In: POPCZYK, Maria (ed). Muæeum sztuki. Od Luwru do Bilbao. Katowice: Wydawnictwo: Muzeum Śląskie, 2006, p. 276.

10 DACOSTA KAUFMANN, Thomas. Remarks on the Collections of Rudolf II: The Kunstkammer as a Form of Representatio. In: Art Journal, 1987, vol. 38, no. 1, p. 22-28 and FORMÁNEK, Václav; HEROLD, Erich KANDERT, Josef, Africké umèni v Ceskoslovensku: výstava v Letobrádku královny Anny v Praze, cerven - srpen 1983. [Exhibition catalogue]. Praze: Správa kulturnich zařízení MK ČSR v nakl. a vydavatelství Panorama, 1983, p.18-21. ${ }^{11}$ ŻYGULSKI, Zdzisław, Muzea na swiecie. Wstep do muzealnictwa. Warszawa: Wydawnictwo Naukowe PWN, 1982, p. 50-51 and DERRICOURT, Robin (2011). Inventing Africa: History, Archaeology and Ideas. London and New York: Pluto Press, 2011, p. 145.
} 
African art objects in ethnological collections

Exploration and the beginnings of the colonial era ended the period dominated by curiosity collecting, in which collected objects served primarily as souvenirs. The classic cabinets of curiosities emerged in the sixteenth century, although more rudimentary collections had existed earlier. In addition to the most famous and best documented cabinets of rulers and aristocrats, members of the merchant class and early practitioners of science in Europe formed collections that were the true precursors to modern museums. Gradually, the gathered memorabilia brought from overseas journeys left the curiosity cabinets and began to appear in newly established ethnographic museums. Initially, African art was exhibited in ethnographic museums, which were created in the colonial era to reflect the remoteness between the metropolis and the primitive African world. Later, these museums turned out to be a true treasury of information about the "Black Continent".

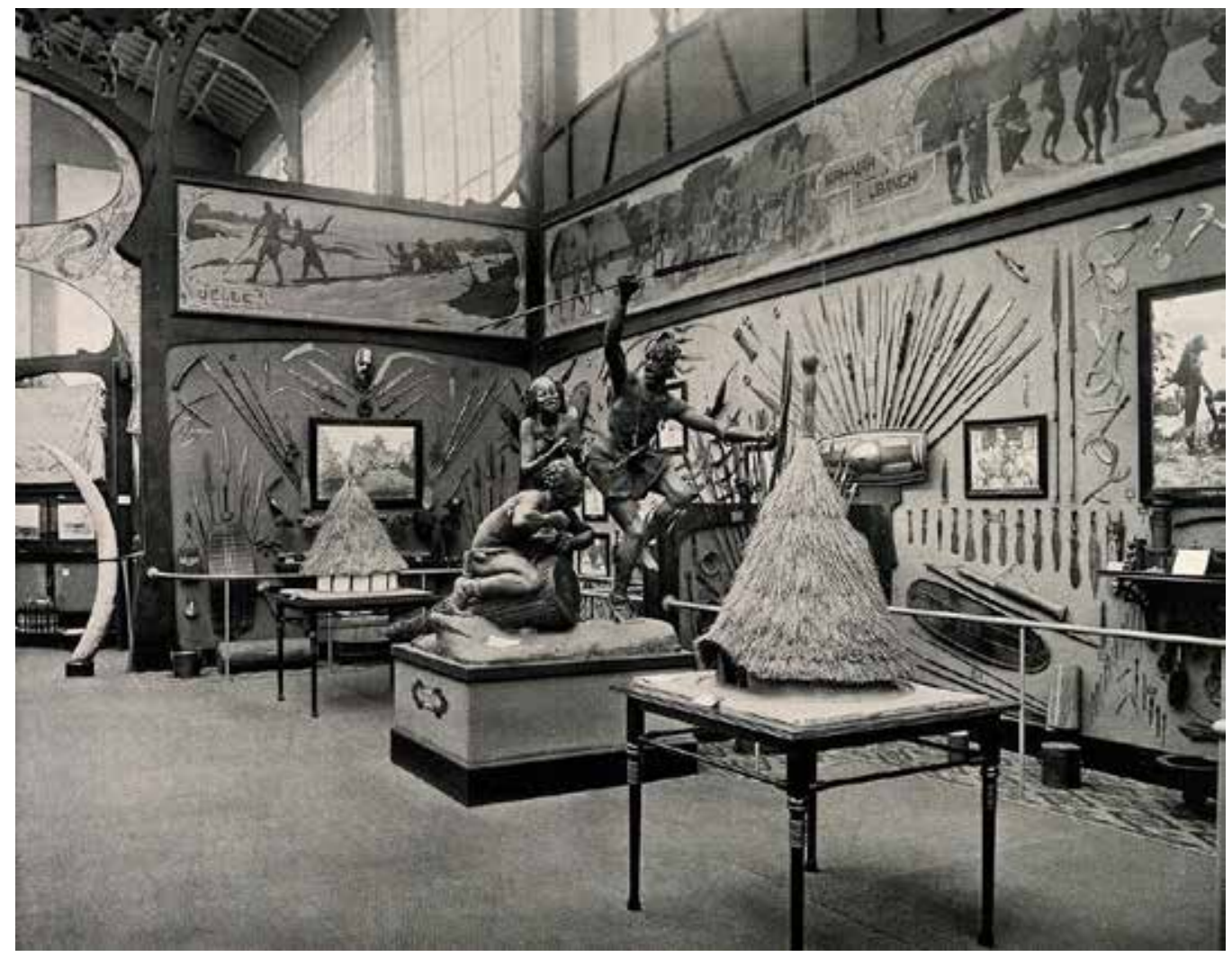

Figure 1: Musée du Congo, Tervuren, Belgium: one of five interior scenes, 1897. Collotype. ${ }^{12}$

An excellent example of an ethnographic collection of great educational value is the compilation of objects from the Berlin Ethnological Museum, which was founded in 1873 and opened its doors in 1886 as the Royal Museum for Ethnology (Königliches Museum für Völkerkunde). But its roots go back to the seventeenth-century Kunstkammer of the rulers of Brandenburg-Prussia. By the time the Berlin Museum für Völkerkunde was open to the public,

12 Wellcome Library, Iconographic Collections, accessed 21 January 2020, http://catalogue.wellcomelibrary.org/ record=b1180754. 
it had already 10,000 African objects on display. ${ }^{13}$

In France the initial public displays of African objects reflected and celebrated mainly the French colonial endeavour. Temporary displays from 1878 onwards, created by Ernest Théodore Hamy, ${ }^{14}$ led to the opening of the Musée d'Ethnographie at the Trocadero in 1882. Four years later, in 1886, an exhibition of the goods plundered by Pierre de Brazza (1852-1905) during the conquests of the West African Expedition attracted 30,000 visitors. ${ }^{15}$

The same colonial approach can be observed in the Royal Museum for Central Africa (Koninklijk Museum voor Midden-Afrika), situated in Tervuren in the Flemish Brabant in Belgium, just outside of Brussels. It was built to showcase King Leopold II's Congo Free State in the 1897 World Exhibition. The exhibition displayed ethnographic objects, stuffed animals and Congolese export products (coffee, cacao and tobacco). In the park, a temporary "Human zoo" was built - which in fact was a copy of an authentic African village, in which 60 Congolese people lived for the duration of the exhibition. ${ }^{16}$

It should be strongly emphasized that starting in the 1870s, in the aftermath of colonial conquests and exploratory expeditions, thousands of African sculptures arrived in Europe. They were placed on view in various museums, such as the Musée d'Ethnographie du Trocadéro and its counterparts in other European cities. At the time, these objects were treated as artefacts of colonized cultures rather than as artworks, and were very cheap, often sold in flea markets and pawnshops. The recognition of these ethnographic curiosities as art was not immediate. Deeper consideration concerning objects originating from Africa emerged in the late nineteenth to early twentieth century. It was only then that celebrated literary works, such as Heart of Darkness by Joseph Conrad (1857-1924), ${ }^{17}$ started to present colonialism not only as a great achievement but also as a truly destructive force, which was not simply concerned with exploring the continent, but also degenerated its inhabitants and corrupted their native culture.

Nevertheless, "primitive" (i.e. "African") culture only very rarely received favourable reviews from European critics; on the contrary, during the most intense years of colonial conquest, the African continent was treated mainly as a cheap source of slave labour, and its inhabitants were believed to have no civilization, not to mention culture or art. ${ }^{18}$ The more unpleasant and hostile stereotypes have been used to support self-serving historical theories about Western domination. These have ranged from the prominent concept, based on the Darwinian theory of evolution, interpreted and popularized by Herbert Spencer (1820-1903), which proclaimed "survival of the fittest" ${ }^{\prime 19}$ and was used to justify the European conquest of other continents,

\footnotetext{
${ }^{13}$ DERRICOURT. Inventing Africa ..., p. 145-146.

${ }^{14}$ PAWLOWSKA. O potrzebie..., p. 276-281.

${ }^{15}$ DERRICOURT. Inventing Africa..., p. 146.

16 "Human zoos," also called ethnological expositions, were 19th- and occasionally 20th-century public exhibitions of humans, usually labelled as in their "natural" or "primitive" state. They were especially popular in the 1870s, when "Human zoos" could be found in Paris, Hamburg, Antwerp, Barcelona, London, Milan and New York City. GRALAK, Zofia. Ludzkie zoo - ciemna strona kolekcjonerstwa. In: Hybris, 2019 vol. 47, 2019, p. 56-74 and Blanchard, Pascal; Bancel, Nicolas; Boëtsch Gilles. Zoos humains et exbibitions coloniales. 150 ans d'inventions de l'Autre. Paris: La Découverte, 2011.

${ }^{17}$ CONRAD, Joseph. The Heart of Darkness. In: Blackwood's Magazine. February 1899-April 1899, vol. 165, p. 164-460, 460-621, 620-781.

${ }^{18}$ See also: PAWLOWSKA, Aneta. Afryka - kontynent bez sztuki i historii? O relatywizmie kultury afrykańskiej. In: JANUS, Joanna \& KNAPEK, Ryszard (ed). Przeszłość bez bistorii. Katowice: Wydawnictwo Gnome, 2007, p. 66-75. ${ }^{19}$ SPENCER Herbert. Principles of Biology. Vol 1. London-Edinburgh: Williams and Norgate, 1864, p. 444.
} 
to the colonial ideology known as the "civilizing mission". ${ }^{20}$ This vision of Africa and its inhabitants allowed many critics and art lovers to ignore the continent's many forms of artistic expression, treating such creations not as works of art (nor their creators as artists) but strictly as bizarre or strange objects whose proper place is, at best, in ethnographic museums. Opinions and attitudes towards African art were also determined by preconceived ideas and philosophies about race, as a result of which the creations of African artists were not categorized as true "art" in the Euro-American sense of the word.

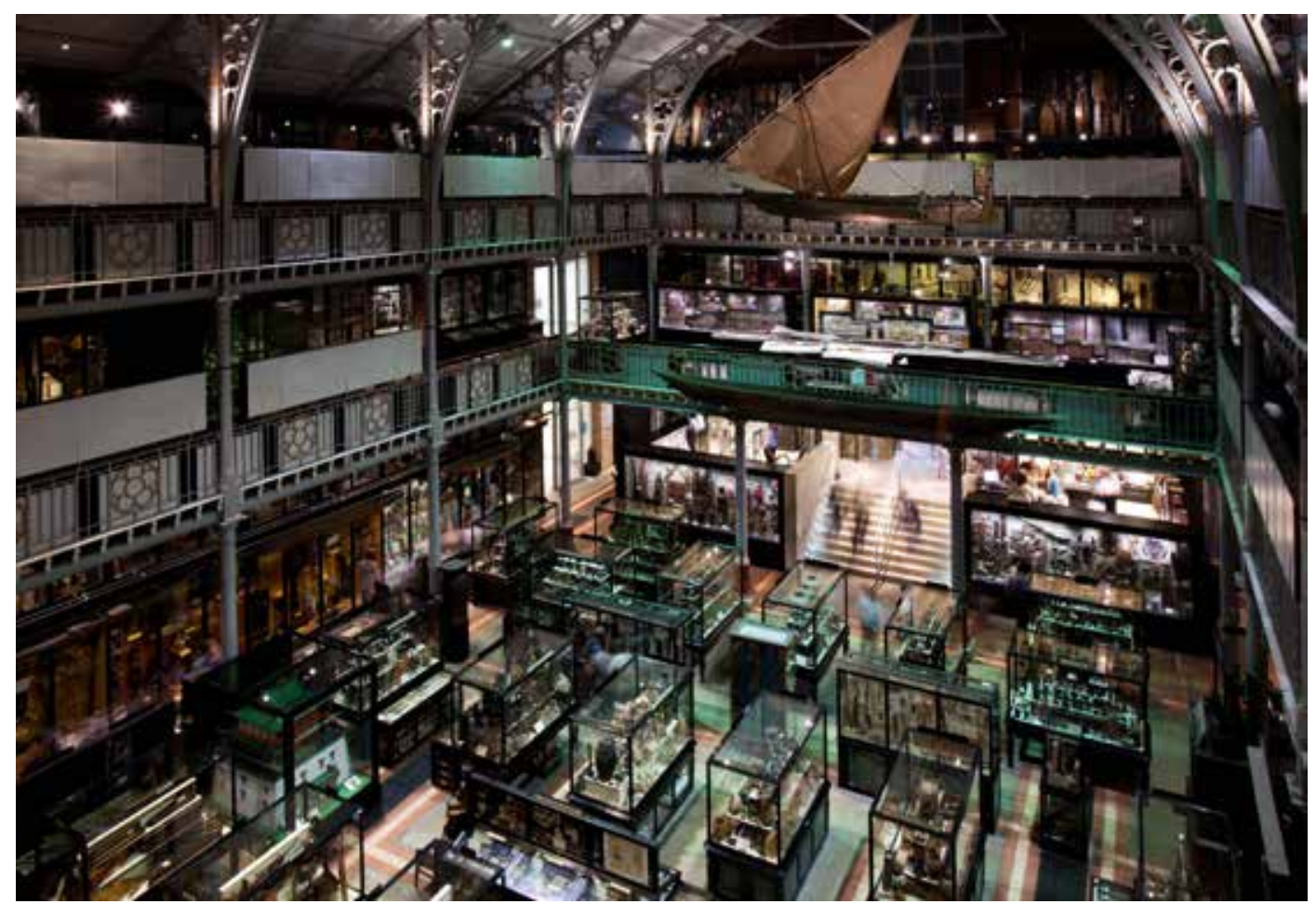

Figure 2. View of archaeological and ethnographic collections. Pitt Rivers Museum, Oxford, 2017. Photo: J. Royan

At this point, I would like to recall the opinion of a prominent South African writer and painter known for his opposition to apartheid - Breyten Breytenbach (b. 1939), who is a white African descendant of the Dutch colonizers of South Africa. Thanks to his "double personality", he can speak on behalf of both opposing groups - the colonized Africans and the white colonizers:

It has always been peculiar to European cultures [...] to conquer, subdue, explore, expand, and exploit; later to maintain conquered territories as sources of raw materials or as markets; to loot and gut the cultures found there, and then to collect their "artefacts" so as to "understand" the broken toys, the images and relics of a broken spirit, and ascribe a "meaning" to them. An anthropology, ethnology, even our modern-day "multiculturalism" [...] are manifestations of greed, the urge for power over the rest of the world, the need to catalogue the "Other" and relegate him to a position of being, at best, "untouched by time", but always inferior. ${ }^{21}$

\footnotetext{
${ }^{20}$ LIEBERSOHN, Harry M. Introduction: The Civilizing Mission. In: Journal of World History, vol. 27, no. 3, 2016, p. 383-387.

${ }^{21}$ BREYTENBACH, Breyten. Notes from the middle world. Chicago: Haymarket Books. 2009, p.1 (emphasis in original).
} 
Breytenbach, although he is white, understands well the negative aspects of colonizing Africa and the subjugation of its people. Similarly, he negatively perceives colonial museums as an expression of the greed and lust for power of the white colonizers.

\section{Changes: Modernists and new interpretations of African artefacts}

Suddenly, in the first decade of the twentieth century, certain proponents of the French Avant-Garde art movement in Paris (such as Pablo Picasso, Georges Braque, Henri Matisse, Maurice de Vlaminck and Andre Derain) began to take a vivid interest in sculptures originating from West and Central Africa. As a result of its influence on these artists' work, African art also came to the notice of art historians. ${ }^{22}$ It was particularly appealing to those seeking creative inspiration from various impulses which their own culture defined as intuitive and primitive.

Such interpretations were founded on the myth of the "primitive man", which tells us more about the Western culture which created such terminology than about the other cultures it has been so readily applied to. Myths of the "primitive man" served as imagined alternatives that could both justify and challenge Western culture, or "civilization" as it was often defined. At various times and places, these myths have employed either demonic images of childlike but bestial savages or utopian visions of "noble savages" - primal, tribal peoples living in harmony with nature. ${ }^{23}$ This romantic trope of "primitive simplicity and purity" has deep roots in Western culture and art. It is evident, for example, in Paul Gauguin's search for both the simple life in his sojourn among Breton peasants, and the exotic life in his escape to live among Tahitians. It can also be seen in the utilisation of non-Western art and ritual practices by the European Avant-Garde movement before the First World War, for example, through Cubism, Fauvism or the works of Die Brücke.

A parallel attitude was presented by Auguste Macke (1887-1914), a renowned German painter who was the leader of Der Blaue Reiter. He suggested that the work of African peoples was worth more to European visual culture than had originally been appreciated. He was shocked at the way "the connoisseurs and artists" had "banished all forms of primitive cultures to the fields of ethnology or applied arts" 24 and felt that, despite the stylistic differences, all art was created to give plastic form to intangible ideas; an intrinsically human trait.

Nevertheless, initially, in Europe in the early twentieth century, the appreciation of African objects purely as fine art was largely limited to private galleries. For example, in Paris, dealers such Paul Guillaume, Charles Ratton and Louis Carre played a significant role in the formation of major private collections of African art. One can observe a similar attitude to African artefacts presented by Stewart Culin (1858-1929), the curator of the Department of Ethnology at the Museum of the Brooklyn Institute of Arts and Sciences, who was among the first curators to recognize displayed ethnological collections as art objects, not as ethnographic specimens. This approach is evidenced in his exhibition entitled Primitive Negro Art, Chiefly from the Belgian Congo.

\footnotetext{
${ }^{22}$ To see more: RUBIN, Wiliam (ed). Primitivsmi in 20th Century Art: Affinity of the Tribal and the Modern. New York: The Museum of Modern Art, vol. 1-2, 1984; PAWLOWSKA, Aneta. Picasso i Afryka. In: The Artistic Traditions of non-European Culture, 2009, vol. 1, p. 163-173 and PAWLOWSKA, Aneta, Avant-gardists and primitivism. In: Art Inquiry. Recherches sur les arts, vol. 19, 2017 p. 153-169 as well as FLAM, Jack, DEUTCH Miriam. Primitivism and Twentieth-Century Art: A Documentary History. Berkeley: University of California Press, 2003.

${ }^{23}$ ROUSSEAU, Jean-Jacques (1762). The Social Contract, ed. BENNETT, Jonathan (2017), accessed 21 January 2020 , www.earlymoderntexts.com/assets/pdfs/rousseau1762.pdf.

${ }^{24}$ MACKE, Auguste. Masks. In: HARRISON, Charles \& WOOD, Paul (eds). Art in Theory, 1900-2000: An anthology of changing ideas. Oxford: Wiley-Blackwell, 2002, p. 96.
} 
The exhibition opened in April 1923, and showed African objects he had acquired from dealers in Europe. ${ }^{25}$ As Culin stated in the exhibition catalogue:

Apart from private exhibitions, designated as artistic, the objects of Negro art which are displayed publicly form part of museum collections of African ethnology and receive no special attention at the hands of ethnologists. The most notable collection is in the Museum of the Congo at Tervueren, Brussels, Belgium. Enormous collections exist also in the museums of ethnology of Berlin and other German cities, in London in the British Museum, in Paris at the Trocadero and in America in Washington, Philadelphia, Cambridge, Chicago, and in New York where the Museum of Natural History contains a vast hall of African ethnology in part derived from the Belgian Congo and presented by H. M. the King of the Belgians. In the majority of these collections their artistic significance is obscured by the wealth of material, and lost, not infrequently, in the efforts made for its elucidation. ${ }^{26}$

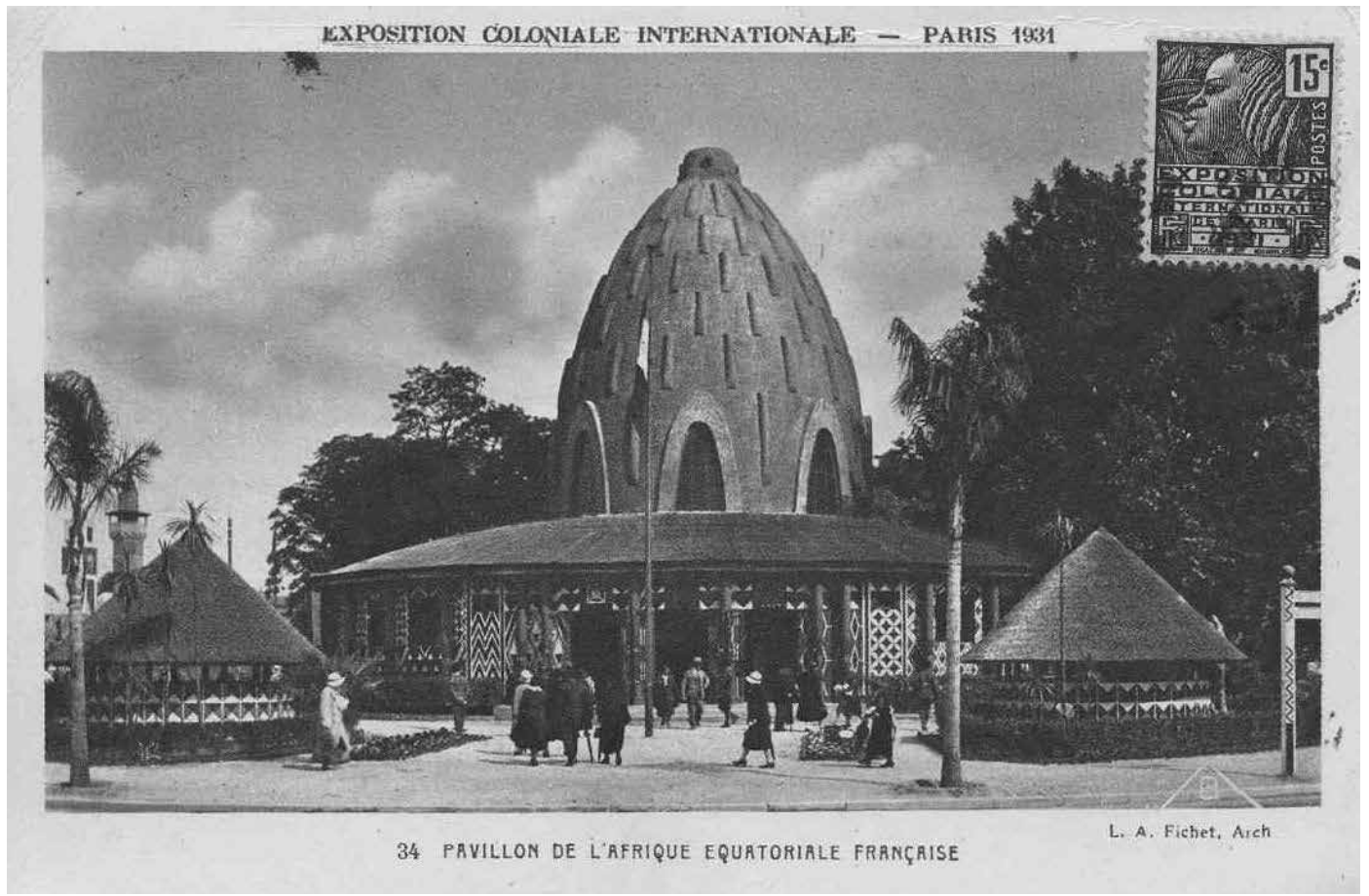

Figure 3: Pavillon de l'Afrique-Équatorialefrançaise [French Equatorial Africa Pavilion], 1931. Postcard. Collection of E. Jedlińska

As was already mentioned above, at the beginning of the twentieth century, growing recognition of African forms and aesthetics stimulated a slowly rising demand for African art objects in Europe. At first, the demand was limited largely to the Cubists and their immediate entourage. But by the 1910s and 20s, the demand for African art in Europe was already spreading to other sectors of society. In France, in particular, the end of World War I brought about an atmosphere which was conducive to engaging the interest of a wider public in the appreciation

\footnotetext{
${ }^{25}$ Research: African Art Exhibition of 1923, accessed 21 January 2020, https://www.brooklynmuseum.org/opencollection/research/pna1923.

${ }^{26}$ CULIN, Stewart. Primitive Negro Art, Chiefly from the Belgian Congo. [Catalogue]. Brooklyn Museum: Department of Ethnology, 1923, p. 5.
} 
and collection of African art. ${ }^{27}$ The disdain in which Africans had previously been held by the great majority of France's population was replaced, after the war, "by a certain curiosity about the customs of these [African] people who had fought fiercely [against the Germans] and were now joyful partners in the victory celebrations". ${ }^{28}$ The success of the African pavilion at the L'Exposition Coloniale de Vincennes in 1931 fuelled even further the demand for African objects in France. ${ }^{29}$ Even after the Cubist movement had ended and many of the artists themselves had lost interest in African art, the market for African art, which they had inspired and helped organise, had already developed its own commercial and economic structure, enabling it to continue and flourish without their support.

\section{Collections and exhibitions of African art after World War II}

The first half of the twentieth century saw great changes in both attitudes and laws concerning African art and artefacts. Western interest in African art grew, and with it came new issues of authenticity and forgery.

Since World War II, important international conferences and conventions (for example, the Hague Convention of 1954 and the UNESCO Convention of 1970) have established an increasing level of protection for cultural property, and thus for African art. Moreover, Nigeria, Mali, Cameroon, Zaire (now the Democratic Republic of the Congo) and the Republic of the Congo all gained independence in $1960 .{ }^{30}$ As the African colonies gained independence, some of them created institutions to honour and protect their cultural heritage. A good example of such an attitude was Ghana. When Ghana became an independent country in March 1957, the Ghana Museums and Monuments Board was created, and a National Museum opened in Accra as a part of the independence celebration. The National Museum featured works from Ghana and other African cultures displayed thematically with objects from different ethnic groups illustrating Ghana's varied cultural heritage. Nkrumah [the first Prime Minister and President of Ghana] also encouraged the National Museum to collect and display objects from African societies outside of Ghana, underscoring Nkrumah's pan-Africanist outlook. Casts of Benin bronzes, Egyptian antiquities and parts of mummies, Senufu masks from Cote d'Ivoire, Zulu wooden figures and beadwork from South Africa, Ife bronze heads from Nigeria, the Bushongo carvings from the Congo were acquired through exchange and included in the permanent exhibits and collections of the Ghana National Museum. ${ }^{31}$

While Ghana created museum exhibitions of African art, American and European museums, galleries and collectors became increasingly interested in African art. In the late 1960s and 1970s, it became trendy to collect "authentic primitive art" from Africa and other locations. In 1964, the Museum of African Art in Washington DC was founded by Warren M. Robbins (1927-2009), initially as a private and relatively small collection. In 1979, the collection, by then comprising about 8,000 objects, was taken over by the Smithsonian Institute. Eventually, in 1981, the Museum of African Art was renamed the National Museum of African Art. ${ }^{32}$ Even

\footnotetext{
${ }^{27}$ STEINER, Christopher B., African Art in Transit. Cambridge: Cambridge University Press, 1994, p. 5.

${ }^{28}$ PAUDRAT, Jean-Louis. From Africa. In: RUBIN, Primitivism..., vol. 1, p. 157.

${ }^{29}$ LAUDE, Jean. The Arts of Black Africa. Berkeley: University of California Press, 1971, p. 20.

${ }^{30}$ NUGENT, Paul. Africa Since Independence. New York: Palgrave Macmillan, 2004, p. 58.

${ }^{31}$ KANKPEYENG, Benjamin W., DECORSE, Christopher R. (2004). Ghana's Vanishing Past: Development, Antiquities, and the Destruction of the Archaeological Record. In: African Archaeological Review, vol. 21, no. 2, 2004 , p. 95.

${ }^{32}$ SIARCHIVES, accessed 21 January 2020, https://siarchives.si.edu/history/national-museum-african-art.
} 
the largest art museum in the United States - The Metropolitan Museum of Art in New York City - opened a Michael C. Rockefeller Wing dedicated only to "Primitive Art" in 1982.

By the second half of the twentieth century, the field of African art, as well as the forms taken by art studies and exhibitions, had changed considerably. In order to illustrate the dynamic changes in the European approach to African Art, it is simply enough to recall William Rubin's famous and controversial exhibition, Primitivism in 20th Century Art at the Museum of Modern Art in New York (1984). At the heart of the debate at the time were the objects that Rubin had enlisted to back up his thesis of the affinity of "tribal" and modern art. Rubin's concern was to show that European artists and those non-European artists dubbed by modernism as primitive were driven by similar aesthetic premises and a similar attitude of mind. ${ }^{33}$ It seems that further ground was broken when the Senegalese figurative sculptor Ousmane Sow and the Nigerian installation artist Mo Edoga (1952-2014) became the first Africans to be included in the prestigious exhibition Documenta 9 (1992). ${ }^{34}$ Since then, African artists have participated in all subsequent Documenta exhibitions (Documenta 10,11, and 12), which are held in Kassel, Germany, every five years. It seems that the visibly growing process of engaging curators of African origin (such as Okwui Enwezor - the first non-European director, Chika OkekeAgulu, Ugochukwu-Smooth, C. Nzewi, Missla Libsekal and Rujeko Hockley) in the creation of exhibitions of modern African art, particularly as a strategy to incorporate the voices of those represented, is one of the most important aspects of the "curatorial turn" of the twenty-first century, presented by Irit Rogoff in her significant essay entitled "Turning". 35

\section{Beyond Compare, is it really so?}

At this point, in order to express the change in attitude towards art from the African continent, I would like to draw attention to the exhibition which was recently presented at the Bode Museum in Berlin (27 October 2017 - 24 November 2019). ${ }^{36}$ This exhibition displayed a complete change of context in relation to African art, moving its presentation from ethnographic museums to a typical art museum. Initially, in 1897, when construction work on the museum's building began, the intention was that the institution should be strictly devoted to only to the most prestigious Renaissance art. Today the Bode Museum houses an extensive collection of sculptures from the medieval period to the late eighteenth century, as well as treasures from the Museum of Byzantine Art and the Numismatic Collection.

The display entitled Beyond Compare introduced splendid works of art from Sub-Saharan

\footnotetext{
${ }^{33}$ RUBIN, William, Modernist Primitivism: An Introduction. In: RUBIN, Primitivism..., vol. 1, p. 11-28.

${ }^{34}$ Documenta is an exhibition of contemporary art which takes place every five years in Kassel, Germany. It was founded by the artist, teacher and curator Arnold Bode in 1955 as part of the Bundesgartenschau (Federal Horticultural Show) which took place in Kassel at that time and was an attempt to bring Germany up to speed with modern art, both banishing and repressing the cultural darkness of Nazism. This first Documenta featured many artists who are generally considered to have had a significant influence on modern art (such as Picasso and Kandinsky). The more recent Documentas feature art from all continents; nonetheless most of it is site-specific. Every Documenta is limited to 100 days of exhibition, which is why it is often referred to as the "museum of 100 days.". Every Documenta is generally regarded as a highly prestigious and celebrated event in the art world. Accessed 21 October 2020, https:// www.documenta.de/en/about\#16_documenta_ggmbh.

${ }^{35}$ I. Rogoff explains that a turn - such as that toward linguistics in the $1970 \mathrm{~s}$ - occurs when an academic discipline is in urgent need of being shaken up, perhaps to the point of discomfort. ROGOFF, Irit (2010). Turning. In: O’NEILL, Paul, WILSON Mick (ed.). Curating and the Educational Turn. London: Open Editions, p. 32-46.

${ }^{36}$ CHAPUIS, Julien, FINE, Jonathan, IVANOV, Paola (ed.) (2017). Beyond Compare. Art from Africa in the Bode Museum. [Catalogue of the Exhibition]. Berlin: Braus Berlin GmbH. Staatliche Museen zu Berlin, 2017.
} 
Africa from the Ethnologisches Museum into the magnificent Renaissance sculpture collection of the Bode Museum.

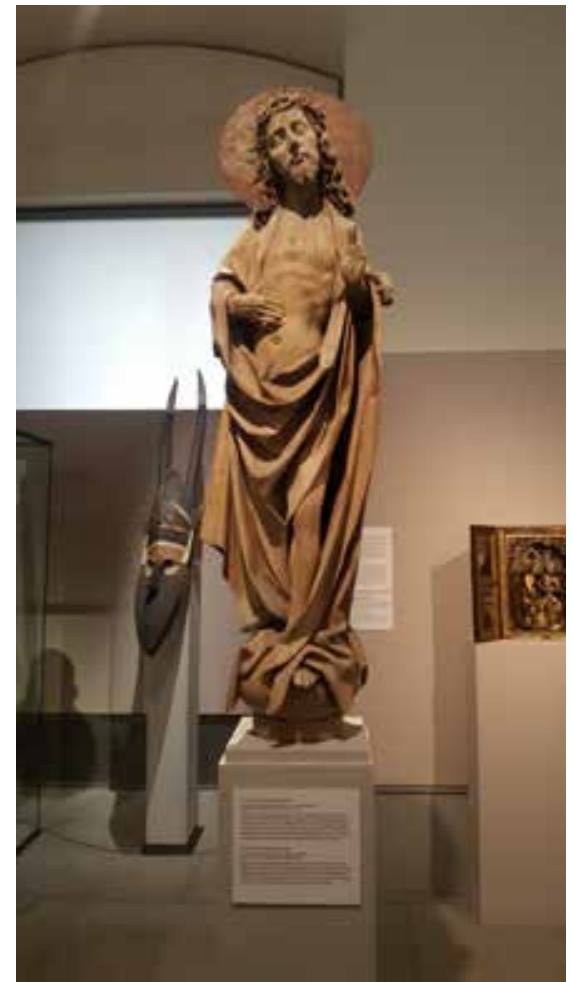

Figure 4: Gothic figure of Christ as the Man of Sorrow and Gabon Mask from the exhibition Beyond Compare, Bode Museum, Berlin, 2019. Photo: A. Pawłowska

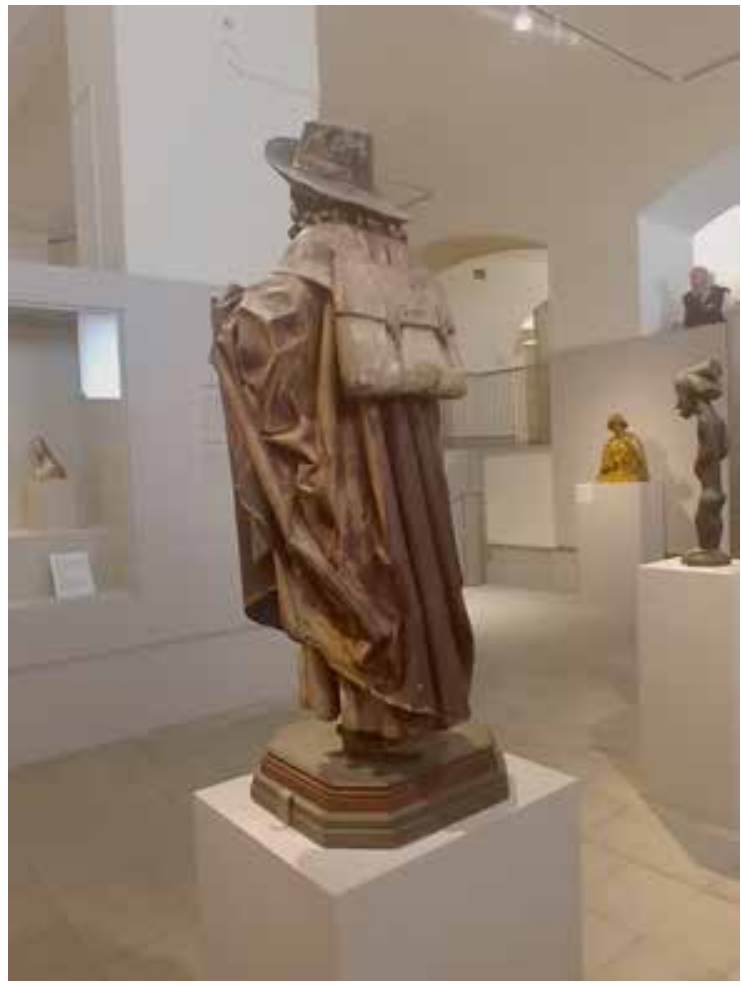

Figure 5: Gotbic figure of St James the Greater and Ancestral Figure (Luba People) Democratric Republic of the Congo from the exbibition Beyond Compare, Bode Museum Berlin, 2019, Photo: I. Gadowska

However, this exhibition raises also several important questions, for which there are no easy answers. What insights can we gain from the joint display of works of art with such different histories? What are the consequences of assigning to separate museums objects of art that once all belonged together in the collection of the Kunstkammer of Brandenburg-Prussia? Why were some of these objects classified as ethnological artefacts and others as works of art? The experimental juxtaposition of works from two continents reveals possible correlations on various levels, including historic contemporaneity, iconographic and technological similarities, and similar artistic strategies. Despite stylistic differences, striking similarities appear in the ways works of art function in both contexts. At the same time, comparisons also expose contrasts, as with depictions of motherhood, which rely on different visual languages in Africa and Europe and convey different messages. Unexpected similarities and differences become apparent: Renaissance sculptor Donatello's Putto with Tambourine seems to invite the Early Modern Princess from the Kingdom of Benin to dance. Michel Erhart's late Gothic Virgin of Mercy appears next to a power figure from the Congo (nkisi; pl. minkisi) which, like the Madonna, was also created to protect the community. The Romanesque Christ seated in Judgment from the Abbey Church of Gröningen and the large Ngilmask from the Fang region of Gabon or Cameroon both present awe-inspiring images of judges. Mythical heroes from Central Africa take their place among 
late Gothic Christian figures and open up new perspectives on both collections. Thus, one can clearly see, the act of comparing and identifying is not neutral, but charged with socially defined prejudices, conventions and constructions of history: Why is one object treated as only "ethnographic," while another is regarded as genuine "art"? What distinguishes a fetish from a reliquary? It seems that in the eyes of the contemporary curators of this exhibition, the masters of both continents are equal and the objects of both of African and European origin, saturated with religious functions, gain the status of a true works of art.

On the other hand, when drawing due attention to the broadly understood term "indigenous Sub-Saharan art", it must be kept in mind that at least older African artefacts and artworks were never created with the intention that they might eventually be found in the collection of an admirer of so-called exotic art or in a Western museum collection. This is because they were dedicated to the community that created them, with some types of sculpture meant to be exposed in dark temples to which only members of a given community had access, whereas other sculptures had a commemorative, apotropaic value or served the function of a personal amulet. A very large proportion of the objects which made it to European collections were connected with live music and dance spectacles, such as masquerades, rites of passage or other religious functions, in which they played a significant role. Thus, all these sculptures, masks and other objects lose their meaning and cultural context forever when they are included in the cultural vision of the world of Western civilization and undergo musealisation in glazed and illuminated display cases. Therefore, no professional description or contextual presentation will restore the original function of the object. ${ }^{37}$

\section{Conclusion: Reappraisal of the concept of African art presented in museums and art galleries}

The immense African continent, with its range of different cultures, has produced many works of art that are original, expressive and represent aspects of the universal search for beauty. ${ }^{38}$ These works, which came to light during the exploration of the continent, aroused a strong fascination among European art connoisseurs. This meeting of the cultures of Africa and of Europe has two aspects. Undoubtedly, knowledge of African art was a revelation and a radical inspiration for European artists, painters, and sculptors from Picasso and Braque to the German Expressionists. The other aspect, however, was African art's misappropriation, following the intrusion of colonization without any respect for the indigenous cultures which produced the art. This brutal transfer of Sub-Saharan artefacts to European museums and to private collections outside of Africa, culturally impoverished the continent. Thus, it has to be said that nowadays the best-known collections of African art heritage are found in Western museums and private collections. Additionally, these collections were largely established during the colonial period. Consequently, most African art was consigned to curio status and presented

\footnotetext{
${ }^{37}$ The issue of Polish museum collections of African art remains a relatively poorly recognised one. Among older studies can be recommended: KORABIEWICZ, Wacław. Sztuka Afryki w z̧biorach polskich. Warszawa: Wydawnictwo Polonia, 1966, or more recently: NADOLSKA-STYCZYŃSKA, Anna. Pośród zabytków z odlegtych stron. Muz̧ealnicy $i$ polskie etnograficzne kolekecje pozaeuropejskiej. Torun: Wydawnictwo Naukowe UMK, 2011, p. 301-319. Thus, the issues related to the ways of presenting artefacts from Africa in the space of the contemporary museum are the subject of the project of "The Implementation Doctorate of the III Edition" (research project No. DWD/3/14/2019 of 30 October 2019, the contract between the Polish Ministry of Science and Higher Education and the University of Łódź) - project manager Professor Aneta Pawłowska, contractor MA Dariusz Skonieczko.

${ }^{38}$ To see more: PAWLOWSKA, Aneta, Aesthetics and Art in Africa: Conceptual Clarification, Confusion or Colonization? In: Art Inquiry. Recherches sur les arts 2007, vol. 9, p. 271-291.
} 
in ethnological collections. Although nowadays African art is very often presented in museums of art, the inevitable questions about the way in which they were acquired, and therefore also about their possible return to their country of origin, remain. The museums participate with an open and constructive attitude in the debates that are being held on this subject and do not shy away from constructive discussions about the future of African cultural heritage in Europe. ${ }^{39}$

In his valuable book, The Predicament of Culture, James Clifford raised the question of cross-cultural translations, challenging the notion of ethnographic authority and asking the fundamental question: "Who has the authority to speak for a group's identity or authenticity?". ${ }^{40}$ His examination of this question is of great relevance to discussions on museum exhibitions as narratives of cultural production from Africa, and to considerations by African artists on and off the continent. Since the mid-1980s, there has been a significant shift in the strategies adopted by museums to enhance participation and to ensure that they remain responsive and relevant to the communities they serve. Of particular interest is the degree to which those who are the focus of an exhibition play a role in their own representation. Increasingly, museum professionals recognize the benefits of exhibition models that rethink the singular, authoritative voice of the museum and embrace the telling of complex, multivocal narratives resonant with the realities of lived experience. An example of such an approach is the Berlin exhibition discussed above. All these aforementioned difficulties and contradictions have compelled some scholars to question the very foundations of African art history, as well as its place in Western museums and art criticism. ${ }^{41}$

\section{References}

BLANCHARD, Pascal, BANCEL, Nicolas, BOËTSCH, Gilles (2011). Zoos humains et exhibitions coloniales. 150 ansd'inventions de l'Autre. Paris: La Découverte. ISBN 2707169978.

BREYTENBACH, Breyten (2009). Notes from the middle world, Chicago: Haymarket Books. ISBN 10: 1931859914.

CHAPUIS, Julien; FINE, Jonathan; IVANOV, Paola (ed.) (2017). Beyond Compare. Art from Africa in the Bode Museum. [Catalogue of the Exhibition]. Berlin: Braus Berlin GmbH. Staatliche Museen zu Berlin. 978-3-86-228-172-5.

\footnotetext{
${ }^{39}$ These issues were discussed at a scientific panel entitled "Afrykańskie muzea w XXI wieku — tożsamość i polityka" [African museums in the twenty-first century - identity and politics] on 30 October 2019 in the framework of the "Afryka na Koszykowej" in Warsaw. The discussion was conducted by Professor Hanna Rubinkowska-Aniol from the Department of African Languages and Cultures from the University of Warsaw. Accessed 21 January 2020 , https://www.koszykowa.pl/bazy-danych/katalogi-centralne/134-debaty-miedzynarodowe/debaty-miedzynarodowe/4972-30-10-2019-afrykanskie-muzea-w-xxi-wieku-tozsamosc-i-polityka.

${ }^{40}$ CLIFFORD, James. The Predicament of Culture, Cambridge MA: Harvard University Press. 1988, p. 8.

${ }^{41}$ Such a position is presented in, for example, a new permanent exhibition on art from Africa, entitled Lebendige Traditionen, Kreative Gegenwart. Kunst aus Afrika (The New World's Art of Africa) at the Fünf Kontinente Museum in Munich. Also, such an attitude is manifested in video work based on a critical interview, with the Congolese painter Francis Mampuya, "Tervuren invisible" (2007), https://boasblogs.org/dcntr/tervuren-invisible/ and in the film "Un-Documented: Unlearning Imperial Plunder" by Ariella Aïsha Azoulay (2019). For more on this, see: SALAMI, Gitti; VISONÀ, Monica Blackmun. A Companion to Modern African Art. Oxford: Wiley Blackwell, 2013 and DE GROOF, Matthias. Statues Also Die - But Their Death is not the Final Word. In: Image \& Narrative vol. 11, no. 1, 2010, p. 29-46.
} 
CLIFFORD, James (1988). The Predicament of Culture. Cambridge, MA: Harvard University Press. ISBN 13: 978-0674698437.

CONRAD, Joseph (1889). The Heart of Darkness. In: Blackwood's Magazine. (February 1899_ April 1899), vol. CLXV, p. 164-460, 460-621, 620-781.

CULIN, Stewart (1923). Primitive Negro Art, Chiefly from the Belgian Congo. [Catalogue]. Brooklyn Museum: Department of Ethnology.

DACOSTA KAUFMANN, Thomas (1987). Remarks on the Collections of Rudolf II: The Kunstkammer as a Form of Representatio. In: Art Journal, vol. 38, no. 1, p. 22-28.

DE GROOF, Matthias (2010). Statues Also Die - But Their Death is not the Final Word. In: Image \& Narrative, vol. 11, no. 1, p. 29-46,

DERRICOURT, Robin (2011). Inventing Africa: History, Archaeology and Ideas. London and New York: Pluto Press. ISBN 978-0-7453-3106-5.

ETOUNGA-MANGUELLE, Daniel (2000). Does Africa a cultural adjustment program? In: HARRISON, Lawrence E \& Huntington, Samuel P. (eds). Culture Matters: How Values Shape Human Progress, (eds) New York: Basic Books, p. 66-77. ISBN 10: 9780465031764.

FLAM, Jack \& DEUTCH Miriam (2003). Primitivism and Twentieth-Century Art: A Documentary History. Berkeley University of California Press. ISBN 13: 978-0520215030.

FORMÁNEK, Václav; HEROLD, Erich KANDERT Josef (1983). Africké umění v Československu: výstava v Letohrádkukrálovny Anny v Praze, červen-srpen 1983. [Exhibition catalogue]. Praze: Správa kulturních zař́zení MK ČSR v nakl. a vydavatelství Panorama.

GLUZIŃSKI, Wojciech (1980). U podstaw muzeologii. Warszawa: PWN. ISBN 978-8301021030.

GRALAK, Zofia (2019). Ludzkie zoo - ciemna strona kolekcjonerstwa. In: Hybris, vol. 47, p. $56-74$.

KANKPEYENG, Benjamin W., DECORSE, Christopher R. (2004). Ghana's Vanishing Past: Development, Antiquities, and the Destruction of the Archaeological Record. In: African Archaeological Review, vol. 21, no. 2, p. 89-128.

KREAMER, Christine Mullen (2003). A Tribute to Roy Sieber. In: African Arts, vol. 36 no. 1, p. $12-23,91$.

KORABIEWICZ, Wacław, Sztuka Afryki w zbiorach polskich, Warszawa: Wydawnictwo Polonia, 1966.

LAUDE, Jean (1971). The Arts of Black Africa, Berkeley: University of California Press. ISBN 13: 9780520023581.

LIEBERSOHN, Harry M (2016). Introduction: The Civilizing Mission. In: Journal of World History, vol. 27, no. 3, p. 383-387.

MACKE, Auguste (2002). Masks. In: HARRISON, Charles \& WOOD, Paul (ed.). Art in Theory, 1900-2000: an anthology of changing ideas, Oxford: Wiley-Blackwell, p. 95-96. ISBN 10: 0631227083.

NADOLSKA-STYCZYŃSKA, Anna. Pośród zabytkón z odlegtych stron. Muzealnicy $i$ polskie etnograficzne kolekecje pozaeuropejskiej. Toruń: Wydawnictwo Naukowe UMK 2011. ISBN: 97883-231-2744-4.

NOWAK, Bronisław (1996). Początki obecności europejskiej w Czarnej Afryce. In: TYMOWSKI, Michał (ed). Historia Afryki do poczatku XIX wieku. Wrocław-WarszawaKraków: Ossolineum, 1996, p. 765-792. ISBN 8304040948.

NUGENT, Paul (2004). Africa Since Independence. New York: Palgrave Macmillan. ISBN 10: 
0333682734.

PAUDRAT, Jean-Louis (1984). From Africa. In: RUBIN, William (ed). Primitivism in 20th Century Art: Affinity of the Tribal and the Modern. New York: The Museum of Modern Art, vol. 1, p. 125-75. ISBN 9780870705182.

PAWLOWSKA, Aneta (2006). O potrzebie tworzenia kolekcji sztuki afrykańskiej. In: POPCZYK, Maria (ed). Muzeum sqtuki. Od Luwru do Bilbao. Katowice: Wydawnictwo: Muzeum Śląskie, p. 272-281. ISBN 83-60353-03-4.

PAWLOWSKA, Aneta (2007). Aesthetics and Art in Africa: Conceptual Clarification, Confusion or Colonization? In: Art Inquiry. Recherches sur les arts 2007, vol. 9, p. 271-291.

PAWŁOWSKA, Aneta (2007). Afryka - kontynent bez sztuki i historii? O relatywizmie kultury afrykańskiej. In: JANUS, Joanna \& KNAPEK, Ryszard (ed). Przeszłość bez historii. Katowice: Wydawnictwo Gnome, p. 66-75. ISBN 978-83-87819-60-6.

PAWLOWSKA, Aneta (2009). Picasso iAfryka. In: The Artistic Traditions of non-European Culture, vol. 1, p. 163-173.

PAWLOWSKA, Aneta (2016). South African museums. Representation and identity in African Studies. In: Pawlak Nina; Rubinkowska-Anioł, Hanna; Will Izabela (ed). Forging New Perspectives and Directions. Warszawa: Elipsa, pp. 216-230. ISBN 978-83-8017-114-5.

PAWLOWSKA, Aneta (2017). Avant-gardists and primitivism. In: Art Inquiry. Recherches sur les arts, vol. 14, p. 153-169.

Research: African Art Exhibition of 1923, accessed 21 January 2020, https://www. brooklynmuseum.org/opencollection/research/pna1923.

ROGOFF, Irit (2010). Turning. In: O’NEILL, Paul \& WILSON Mick (ed.). Curating and the Educational Turn, London: Open Editions, p. 32-46. ISBN 13: 978-0949004185.

ROUSSEAU, Jean-Jacques (1762; 2017). The Social Contract. BENNETT Jonathan (ed.), accessed 21 January 2020, www.earlymoderntexts.com/assets/pdfs/rousseau1762.pdf.

RUBIN, Wiliam (1984) Modernist Primitivism: An Introduction. In: RUBIN, William (ed). Primitivism in 20th Century Art: Affinity of the Tribal and the Modern. New York: The Museum of Modern Art, vol. 1, p. 1-28. ISBN 9780870705182.

SALAMI, Gitti, VISONÀ, Monica Blackmun (2013) A Companion to Modern African Art. Oxford: Wiley Blackwell. ISBN: 9781444338379.

SAXL, Fritzl (1976). Po co nam historia sztuki. In: BIAŁOSTOCKI, Jan (ed). Pojecia, problemy, metody wspótczesnej nauki o sztuce. Warszawa: PWN, p. 14-28.

SIARCHIVES, accessed 21 January 2020, https:/ / siarchives.si.edu/history/national-museumafrican-art.

SIEBER, Roy (1984). Preface. In: GILLON, Werner. A Short History of African Art. London: Viking. p.11-14. ISBN 10: 0670800554.

SPENCER Herbert (1864). Principles of Biology. Vol 1. London-Edinburgh: Williams and Norgate.

STEINER Christopher (1994). African Art in Transit, Cambridge: Cambridge University Press. ISBN: 10: 0521457521.

STOCKING, George (1983). History of Anthropology: Whence/Whither. In: STOCKING, George (ed.). Observers Observed: Essays on Ethnographic Fieldwork. Madison, Wis: University of Wisconsin Press, p. 3-12. ISBN 0-299-09450-2.

TYMOWSKI, Michał (2017). Europejczycy i Afrykanie: Wrajemne odkrycia i pierwsze kontakty. Toruń Wydawnictwo Naukowe Uniwersytetu Mikołaja Kopernika. ISBN 978-83-231-3719-1. 
A. Pawłowska: African Art: The Journey from Ethnological Collection...

ŻYGULSKI, Zdzisław (1982). Muzea na świecie. Wstęp do muz̨ealnictwa. Warszawa: Wydawnictwo Naukowe PWN. ISBN: 83-01-03095-X. 